Asian J. Med. Biol. Res. 2017, 3 (1), 80-87; doi: 10.3329/ajmbr.v3i1.32041

\author{
Asian Journal of \\ Medical and Biological Research \\ ISSN 2411-4472 (Print) 2412-5571 (Online) \\ www.ebupress.com/journal/ajmbr
}

\title{
Article \\ Breeding for the improvement of indigenous chickens of Bangladesh: performance of foundation stock
}

\author{
Shakila Faruque $^{1}$, A.K.F.H. Bhuiyan ${ }^{2}$, Md. Yousuf $\mathrm{Ali}^{3^{*}}$ and Ziaul Faruque Joy ${ }^{4}$ \\ ${ }^{1}$ Poultry Production Research Division, Bangladesh Livestock Research Institute, Savar, Dhaka-1341, \\ Bangladesh \\ ${ }^{2}$ Department of Animal Breeding and Genetics, Bangladesh Agricultural University, Mymensingh-2202, \\ Bangladesh \\ ${ }^{3}$ Bangladesh Livestock Research Institute, Regional Station, Baghabari, Shahjadpur, Sirajgonj-6770, \\ Bangladesh \\ ${ }^{4}$ Department of Genetic Engineering and Biotechnology, Shahjalal University of Science and Technology, \\ Sylhet-3114, Bangladesh
}

*Corresponding author: Md. Yousuf Ali, Bangladesh Livestock Research Institute, Regional Station, Baghabari, Shahjadpur, Sirajgonj, Bangladesh. E-mail: 113yousuf.bau@gmail.com, myousuf@blri.gov.bd

Received: 28 February 2017/Accepted: 21 March 2017/ Published: 30 March 2017

\begin{abstract}
Selection is one of the vital tools for improving the indigenous chicken genetic resources. A total of 1585-day-old chicks comprising of 3 types of chicken namely Naked Neck (NN), Hilly (H) and Non-descript Deshi (ND) were hatched for this study to form foundation stock. Improvement target of egg weight was to increase by $1 \mathrm{~g}$ and improvement target of egg production rate was to increase by $2 \%$ per generation. In foundation stock, selection was practiced at 40 -week of age, on the basis of an index comprising the parameters of age at first egg (ASM), body weight(BW), egg production(EP) and egg weight(EW). Data were analyzed in CRD by General Linear Model (GLM) Univariate Procedure. Significantly highest fertility $(82.71 \%)$ and hatchability $(82.20 \%)$ were found in ND genotype. Significantly $(\mathrm{P}<0.001)$ highest body weight of day-old chicks and daily weight gain was found in $\mathrm{H}$ genotype than other two genotypes. There was a non-significant $(\mathrm{P}>0.05)$ variation in FCR among the native chicken genotypes. NN genotype (3.46\%) had non-significantly $\left(\chi^{2}\right.$ $=3.62 ; \mathrm{P}>0.05)$ higher chick mortality than $\mathrm{ND}(1.63 \%)$ and $\mathrm{H}(2.11 \%)$ at brooding period $(0-4$ weeks). Significantly $(\mathrm{P}<0.01)$ higher dressing percentage was found in NN (64.58) genotype than ND (60.26) and $\mathrm{H}$ (61.70) genotypes. Non-significantly higher egg production in selected group was found in $\mathrm{H}$ (70) genotype than ND (68) and NN (67) genotypes. Significantly $(\mathrm{P}<0.001)$ highest shape index and Haugh unit were found in $\mathrm{H}$ and ND genotypes, respectively. As a result of selection, egg production is expected to improve by 0.562 , 0.932 and $0.755 \%$, respectively for ND, $\mathrm{H}$ and $\mathrm{NN}$ genotypes. In terms of reproductive traits ND was superior, in terms of productive traits $\mathrm{H}$ genotype was superior and in terms of dressing percentage and breaking strength NN genotype was superior. These findings of the study also give an impetus for continuing the research for more generations to fulfill the objectives of the long-term programme.
\end{abstract}

Keywords: indigenous chicken; selective breeding; genotype; performance

\section{Introduction}

Poultry especially chicken is the cheapest source of animal protein in the form of meat and eggs throughout the world including Bangladesh (Simon, 2009). It is estimated that there are 188 million chickens including commercial hybrids as well as native chickens (BBS, 2006). Due to extreme pressure of increasing population on food, most of the developing countries are suffering from malnutrition. In our daily diets, an egg contributes a good portion of our daily nutritional requirements as additives serves as supplementary food for any age that 
meet the protein deficiency. People always try to find the indigenous (Deshi) cockerel for its tenderness and special taste (Ahmed and Ali, 2007). Though the price of Deshi chicken is more than broiler (Islam, 2003) and are more demanded compared to broiler meat. Recent studies showed that despite their low overall productivity indigenous chicken display wide range of variability in terms of morphological, production and genetic characteristics (Halima, 2007) implying the potential for improvement through selective breeding. A study conducted by Faruque et al. (2010a) under intensive management in three indigenous chicken genotypes viz. Non-descript deshi, Hilly and Naked Neck have shown existence of significant variation in various traits and hence expecting adequate response to selection. There are very few examples of pure breeding programs for indigenous birds in Bangladesh and around the world. Therefore considering the above situation this study was undertaken with the objectives of; i) to compare the productive and reproductive performances of foundation stock of 3 native genotypes under intensive management, ii) to improve the genetic potentiality of Indigenous chicken genotypes for selected economic trait(s) through successive generations of pure breeding and iii) to recommend suitable tools /techniques / methods for the improvement of native chickens of Bangladesh.

\section{Materials and Methods}

\subsection{Formation of foundation stock}

As a part of selection and improvement of indigenous chicken, the Poultry Production Research Division (PPRD) of BLRI to date collected 5 types of indigenous chicken on the basis of phenotypic characteristics of birds to continue the said breeding program. But the individuals were not selected on the basis of their selection index value/breeding value. As a first step, it is necessary to establish a foundation stock. Foundation stock was established utilizing the existing stock of BLRI as well as by incorporating variation through screening of males/females/eggs from wider indigenous chicken gene pool of Bangladesh.

\subsection{Selection of egg collection area}

The representative areas on the basis of availability of chicken were selected namely Bandarban, Naikhongchari, Rangamati, Chockoria, Sherpur (Jhinaigati), Mymensingh, Dhaka (Dhamrai), Manikganj (Shibaloy, Horirampur, Saturia, Ghior), Kishoreganj, Sirajganj (Baghabari) and Borguna for egg collection.

\subsection{Fertile egg collection and production of experimental chicks}

A total of 4688 eggs (NN-1683, H- 1546 and ND-1459) were collected from different parts of Bangladesh. In this regards, a group of MS students of Bangladesh Agricultural University were engaged for collecting the hatching eggs. Collected eggs were hatched in Poultry Production Research Division (PPRD). Chicks were obtained from two hatches. A total of 1585 day-old chicks were used in this study comprising of $918 \mathrm{ND}, 378 \mathrm{H}$ and $289 \mathrm{NN}$.

\subsection{Breeding and experimental design}

\begin{tabular}{|c|c|c|c|c|c|c|c|}
\hline \multirow{2}{*}{$\begin{array}{l}\text { Name of } \\
\text { genotype }\end{array}$} & \multirow[t]{2}{*}{ Sex } & \multirow{2}{*}{$\begin{array}{l}\text { No. of day } \\
\text { old chicks }\end{array}$} & \multicolumn{2}{|c|}{ No. of growing chicks } & \multirow{2}{*}{$\begin{array}{l}\text { No. of adult } \\
\text { birds }\end{array}$} & \multicolumn{2}{|c|}{ No. of selected bird } \\
\hline & & & 8 wks & 16 wks. & & Selected & Spare \\
\hline \multirow[t]{2}{*}{ ND } & Male & 918 & 85 & 40 & 40 & 16 & 10 \\
\hline & Female & & 230 & 200 & 200 & 80 & 20 \\
\hline \multirow[t]{2}{*}{$\mathrm{H}$} & Male & 378 & 45 & 20 & 20 & 8 & 5 \\
\hline & Female & & 115 & 100 & 100 & 40 & 10 \\
\hline \multirow[t]{2}{*}{ NN } & Male & 289 & 45 & 20 & 20 & 8 & 5 \\
\hline & Female & & 115 & 100 & 100 & 40 & 10 \\
\hline
\end{tabular}

\subsection{Selection objective}

Improvement target of egg weight was to increase by $1 \mathrm{~g}$ and improvement target of egg production rate was to increase by $2 \%$ per generation.

\subsection{Selection criteria}

In foundation stock, selection were practiced at 40-week of age, on the basis of an index comprising the parameters of age at first egg (days), body weight (g) at 40 weeks of age, egg production (\%) (168-280 days) and egg weight $(\mathrm{g})$ at 40 weeks of age etc. 
The selection Index was computed by the following equation:

$$
\begin{aligned}
& \text { Selection Index }(I)=b_{1} x_{1}+b_{2} x_{2}+\ldots \ldots \ldots \ldots+b_{n} x_{n} \\
& \text { Where, } \begin{array}{r}
x_{1}, x_{2}, \ldots \ldots . x_{n} \text { represent the phenotypic value for the trait } \\
b_{1}, b_{2}, \ldots \ldots . b_{n} \text { denote the relative weight given to each of the trait }
\end{array}
\end{aligned}
$$

The total score was obtained from above calculation is a selection index. The individual with the higher total score was selected for breeding purposes. Both index selection and independent culling levels were used to select chicken.

\subsection{Mating design}

In foundation stock, selected males and females were mated at the ratio of 1: 5 using artificial insemination. Selected cocks/sire was mated with hens that were produced by different sire. A rotational mating design was followed to keep inbreeding as low as possible.

\subsection{General flock management}

\subsubsection{Housing}

The chicks were brooded and reared up to 16 weeks of age with individual wing band in a brooding and growing house in an open sided semi gable type roof with concrete floor. The adult birds were reared in a cage individually. After 16 weeks of age all female and male birds were transferred into individual cage and maintain individual feeder and drinker. The house and cages were cleaned, washed and then disinfected before starting the experiment.

\subsubsection{Feeding}

Concentrate mixtures feed that contain 20.06\% Crude Protein \& $2908 \mathrm{Kcal} \mathrm{ME} / \mathrm{kg} \mathrm{DM} ; 18.13 \%$ Crude Protein \& $2904 \mathrm{Kcal} \mathrm{ME} / \mathrm{kg}$ DM and $16.33 \%$ Crude Protein \& $2845 \mathrm{Kcal} \mathrm{ME} / \mathrm{kg}$ DM were provided twice daily in the morning and evening during brooding, growing and laying period, respectively. Cool clean drinking water was supplied all the times.

\subsubsection{Brooding and management}

Pedigree chicks were leg-banded at day old. Day-old chicks collected from the two hatches were individually weighed and transferred in pens into the brooder. They were provided 5\% glucose solution for the first six hours. Vitamins were also added to drinking water. Brooding was done by fitting 100 watts electric bulbs and then heat was decreased gradually by lifting up the bulbs as per requirement of the temperature. After 14 days leg-band was pulled out from leg and applied to wings. Debeaking was performed after 10-12 days of age. All chicks were vaccinated as per schedule given by veterinarian.

\subsubsection{Lighting program}

The photoperiod for brooding period was started at 24 hours/day reduced @ 1 hour/week. Depending on season and day length photoperiod was maintained for layer birds. All the birds were reared in a natural-ventilated poultry house and a $16 \mathrm{~h}$ photoperiod with $12 \mathrm{~h}$ sunlight and $4 \mathrm{~h}$ artificial lights.

\subsection{Recording system}

Records were kept on day-old weight (g), fortnightly individual body weight up to 8 weeks, monthly weight up to 20 weeks, daily egg production, and egg weight at 40 weeks of age, temperature and humidity, growth rate, feed intake and feed conversion ration (FCR). At 12 weeks of age, six birds from each genotype were slaughtered to analyze the meat yield traits. Egg quality characteristics i.e. egg weight, egg length, egg width, shape index, albumen index, yolk index, Haugh Unit, yolk color, albumen height, yolk height, blood spot, meat spot were measured and recorded at $38^{\text {th }}$ weeks of age.

\subsection{Statistical analysis}

All recorded data were analyzed by Generalized Linear Model (GLM) procedure using SPSS 11.5 for Windows (SPSS, 1998). For all statistical purposes the theory of Snedecor and Cochran (1989) were followed. The present data used in the study were from three different genotypes and the structures of data were unbalanced (Table 1). 
2.11. Prediction of expected selection response

Expected selection response in three types of Indigenous chicken for egg production, egg weight, body weight and age at sexual maturity was estimated for foundation stock using the following equation (Falconer, 1981).

$$
\begin{aligned}
& \mathrm{R}=1 / 2 \mathrm{~h}^{2} \times \mathrm{S}_{\mathrm{f}} \\
& \text { where, } \\
& \mathrm{R}=\text { Expected response in mass selection } \\
& \mathrm{h}^{2}=\text { heritability, } \mathrm{h}^{2} \text { of EP, EW, ASM and BW } \\
& \mathrm{S}_{\mathrm{f}}=\text { Selection differential for dam. }
\end{aligned}
$$

\section{Results and Discussion}

\subsection{Fertility and hatchability}

Significantly $(\mathrm{P}<0.001)$ lowest fertility $(46.69 \%)$ was found in $\mathrm{H}$ genotype (Table 1$)$. The lowest result obtained may be there was serious shortage of sound male birds in the villages. Most of them shared breeding males with neighbours. The villagers didn't maintain the male-female ratio. Nutritional status is also another factor for reducing the fertility rate. (Kirk et al.1980) observed that fertility declined approximately $11 \%$ from 34 to 60 week of hen age. (Faruque et al. 2011) reported that fertility percentage ranged from 84.95 to $97.57 \%$ in ND, H and NN genotypes in intensive management using artificial insemination. Lowest hatchability was found in NN (75.62\%) genotype. This finding is little bit higher than the findings of (Faruque et al. 2011) who found the hatchability on fertile eggs in NN genotype was $60.60,65.07$ and $68.85 \%$ respectively for first, second and third batches.

\subsection{Body weight, weight gain, feed consumption and FCR}

The average initial body weights of day-old chicks of ND, H and NN were 27.74, 28.00 and $24.96 \mathrm{~g}$, respectively and the difference was significant $(\mathrm{P}<0.001)$ (Table 2). (Faruque et al. 2007) found that the body weight at hatch for $\mathrm{ND}, \mathrm{H}$ and $\mathrm{NN}$ genotypes was $31.2,30.5,31.7 \mathrm{~g}$, respectively under intensive management system which was much higher than the present study. Significantly $(\mathrm{P}<0.001)$ highest daily weight gain was found in $\mathrm{H}$ genotype at all stages. At four weeks of age; the $\mathrm{ND}, \mathrm{H}$ and $\mathrm{NN}$ genotypes had the mean growth rate of 3.53, 3.72 and $3.39 \mathrm{~g}$ per bird per day, respectively. These findings are more or less similar to the findings of Halima (2007) who found the average growth rate of 3.30, 3.80, 3.50, 3.60 and 4.00 g respectively for Gassay, Tilili, Gelila, Debre-Elias and Guangua indigenous chicken of Ethiopia. From 4-20 weeks of age, the mean daily body weight gain ranged from $8.39 \mathrm{~g}$ in $\mathrm{NN}$ genotype to $10.26 \mathrm{~g}$ in $\mathrm{H}$ genotype. From $0-20$ weeks of age, the average body weight gains of ND, $\mathrm{H}$ and NN were 7.59, 9.04 and $7.48 \mathrm{~g}$, respectively. Halima (2007) reported that at $0-22$ weeks of age, mean body weight gains of 7.56, 7.52, 6.67, 7.77, 6.58, 7.92 and $7.98 \mathrm{~g}$, respectively for Tilili, Gelila, Debre-Elias, Melo-Hamusit, Gassay, Guangua and Mecha indigenous chickens of Ethiopia. The daily feed intake was affected by genotype at 4-20 and 0-20 weeks of age $(\mathrm{P}<0.001)$ which is shown in Table 3 but daily feed intake was not affected by genotype at $0-4$ weeks of age. There was a non-significant $(\mathrm{P}>0.05)$ variation in FCR among the native genotypes at all stages. Growth rate affected feed conversion. From 0-4 weeks of age, feed conversion ratio (feed:gain) varied from 3.16 in $\mathrm{H}$ genotype to 3.56 in $\mathrm{NN}$ genotype. Yeasmin (2001) found feed conversion ratio during 0-4 week growth period in DN (desi normal) and DD (desi dwarf) to be 3.55 and 5.50, respectively. At the end of the growth period (0-22 weeks), Halima (2007) found FCR was 11.89, 13.14, 13.10, 11.08, 13.87, 10.97 and 11.56, respectively for Tilili, Gelila, Debre-Elias, MeloHamusit, Gassay, Guangua and Mecha indigenous chickens of Ethiopia. These findings are much higher than our present findings.

\subsection{Mortality}

NN genotype (3.46\%) had non-significantly $\left(\chi^{2}=3.62 ; \mathrm{P}>0.05\right)$ higher chick mortality than ND $(1.63 \%)$ and $\mathrm{H}$ $(2.11 \%)$ at brooding period (0-4 weeks) which is shown in Table 3. Khatun et al. (2005) reported that mortality rate was slightly lower in Nakel Neck than Desi and Hilly chicken. Mortality rate of native genotypes at brooding period were $0-2.0 \%$ (Faruque et al., 2007) under intensive condition.

\subsection{Carcass characteristics}

The results of this study show the heavier weight of $\mathrm{H}$ genotype than other two genotypes (Figure 1). Live weights at slaughter at common age did not differ $(\mathrm{P}>0.05)$ among genotypes. Significantly $(\mathrm{P}<0.01)$ higher dressing percentage was found in NN (64.58) genotype than ND (60.26) and H (61.70) genotypes. Breast meat 
weight as percentage of live weight was not affected by genotype but thigh plus drumstick weight as percentage of live weight was affected $(\mathrm{P}<0.05)$ by genotype (Table 4). Hossain et al. (1991) found that Naked Neck indigenous had $1.5 \%$ higher dressing percent and $2.3 \%$ more total meat than that in broiler chicken.

Table 1. Fertility (\%) and hatchability (\%) of collected indigenous chicken eggs.

\begin{tabular}{lllll}
\hline Parameter & \multicolumn{3}{c}{ Genotype } & Significance \\
\cline { 2 - 4 } & ND & H & NN & \\
\hline Fertility (\%) & $82.71^{\mathrm{a}}$ & $46.69^{\mathrm{c}}$ & $54.52^{\mathrm{b}}$ & $\mathrm{P}<0.001$ \\
Hatchability (\%) on fertile eggs & $82.20^{\mathrm{a}}$ & $77.07^{\mathrm{ab}}$ & $75.62^{\mathrm{b}}$ & $\mathrm{P}<0.05$ \\
Dead in germ (\%) & $16.61^{\mathrm{c}}$ & $34.72^{\mathrm{a}}$ & $27.59^{\mathrm{b}}$ & $\mathrm{P}<0.001$ \\
\hline
\end{tabular}

${ }^{a, b, c}$ Means within a row with no common superscripts differ significantly at $(\mathrm{P}<0.05)$ and $(\mathrm{P}<0.001)$

Table 2. Performance of indigenous chicken of foundation stock during brooding and growing period.

\begin{tabular}{llllll}
\hline \multicolumn{1}{c}{ Parameter } & $\begin{array}{l}\text { Age } \\
\text { (week) }\end{array}$ & ND & G & NN & Significance \\
\cline { 3 - 5 } & & $27.74^{\mathrm{a}}$ & $28.00^{\mathrm{a}}$ & $24.96^{\mathrm{b}}$ & $\mathrm{P}<0.001$ \\
& $0-4$ & $3.53^{\mathrm{b}}$ & $3.72^{\mathrm{a}}$ & $3.39^{\mathrm{c}}$ & $\mathrm{P}<0.001$ \\
Day old weight (g) & $4-20$ & $8.47^{\mathrm{b}}$ & $10.26^{\mathrm{a}}$ & $8.39^{\mathrm{b}}$ & $\mathrm{P}<0.001$ \\
Daily weight gain (g/b) & $0-20$ & $7.59^{\mathrm{b}}$ & $9.04^{\mathrm{a}}$ & $7.48^{\mathrm{b}}$ & $\mathrm{P}<0.001$ \\
& $0-4$ & 11.66 & 11.82 & 12.08 & $\mathrm{NS}$ \\
Daily feed intake (g/b) & $4-20$ & $41.36^{\mathrm{c}}$ & $49.64^{\mathrm{a}}$ & $45.38^{\mathrm{b}}$ & $\mathrm{P}<0.001$ \\
& $0-20$ & $35.25^{\mathrm{c}}$ & $41.84^{\mathrm{a}}$ & $38.55^{\mathrm{b}}$ & $\mathrm{P}<0.001$ \\
& $0-4$ & 3.37 & 3.16 & 3.56 & $\mathrm{NS}(\mathrm{P}=0.054)$ \\
Feed conversion (kg feed/kg gain) & $4-20$ & 4.99 & 4.83 & 5.40 & $\mathrm{NS}(\mathrm{P}=0.284)$ \\
& $0-20$ & 4.80 & 4.65 & 5.15 & $\mathrm{NS}(\mathrm{P}=0.408)$ \\
\hline
\end{tabular}

${ }^{\mathrm{a}, \mathrm{b}, \mathrm{c}}$ Mean within a row with no common superscripts differ significantly at $(\mathrm{P}<0.001)$

Table 3. Effect of genotype on chick mortality (\%) at brooding period (0-4 weeks).

\begin{tabular}{llllll}
\hline Genotype & ND & H & NN & $\chi^{\mathbf{2}}(\mathbf{d f}=\mathbf{2})$ & P-Value \\
\hline Mortality (\%) & 1.63 & 2.11 & 3.46 & 3.62 & P $>0.05$ \\
\hline
\end{tabular}

Table 4. Effect of genotype on carcass characteristics.

\begin{tabular}{lllll}
\hline Parameter & \multicolumn{3}{c}{ Genotype } & Significance \\
\cline { 2 - 4 } & ND & H & NN & \\
\hline Live weight at 12 weeks (g) & 862.00 & 869.80 & 848.40 & $\mathrm{P}>0.05$ \\
Dressing \% & $60.26^{\mathrm{b}}$ & $61.70^{\mathrm{b}}$ & $64.58^{\mathrm{a}}$ & $\mathrm{P}<0.01$ \\
Breast meat weight as \% of live weight & 10.40 & 9.37 & 10.64 & $\mathrm{P}>0.05$ \\
Thigh plus drumstick weight as \% of live weight & $17.76^{\mathrm{b}}$ & $19.14^{\mathrm{a}}$ & $19.64^{\mathrm{a}}$ & $\mathrm{P}<0.05$ \\
\hline
\end{tabular}

${ }^{\mathrm{ab}}$ Means with dissimilar superscripts in a row are significantly different

Table 5. Egg production (No) performance of indigenous chicken (EP: 24-40 weeks=112 days).

\begin{tabular}{|c|c|c|c|c|c|}
\hline \multirow[t]{2}{*}{ Parameter } & \multirow[t]{2}{*}{ Group } & & & & \multirow[t]{2}{*}{ Significance } \\
\hline & & ND & $\mathbf{H}$ & $\mathbf{N N}$ & \\
\hline \multirow[t]{2}{*}{ Average } & Selected & $68(60.7 \%)$ & $70(62.5 \%)$ & $67(59.8 \%)$ & $\mathrm{NS}(\mathrm{P}=0.07)$ \\
\hline & Whole & $60^{\mathrm{a}}(53.6 \%)$ & $56^{\mathrm{b}}(50.0 \%)$ & $55^{\mathrm{b}}((49.1 \%)$ & $\mathrm{P}<0.01$ \\
\hline \multirow[t]{2}{*}{ Maximum } & Selected & $83((74.1 \%)$ & $89((79.4 \%)$ & $76(67.8 \%)$ & \\
\hline & Whole & $83(74.1 \%)$ & $89(79.4 \%)$ & $79(70.5 \%)$ & \\
\hline \multirow[t]{2}{*}{ Minimum } & Selected & $61(54.4 \%)$ & $57(50.8 \%)$ & $56(50.0 \%)$ & \\
\hline & Whole & $21((18.7 \%)$ & $15(13.4 \%)$ & $21(18.7 \%)$ & \\
\hline
\end{tabular}


Table 6. Effect of genotype on egg quality.

\begin{tabular}{lllll}
\hline Parameter & \multicolumn{3}{c}{ Genotype } & \multicolumn{2}{l}{ F - value and } \\
& ND & H & NN & Significance \\
\hline Egg weight $(\mathrm{g})$ & 42.15 & 40.08 & 41.00 & $2.023 \mathrm{NS}$ \\
Shape index & $77.56^{\mathrm{a}}$ & $79.20^{\mathrm{a}}$ & $70.57^{\mathrm{b}}$ & $29.68^{* * *}$ \\
Breaking strength $(\mathrm{kg} / \mathrm{cm})$ & 0.342 & 0.358 & 0.383 & $1.827 \mathrm{NS}$ \\
Haugh unit & $77.06^{\mathrm{a}}$ & $66.10^{\mathrm{b}}$ & $76.21^{\mathrm{a}}$ & $12.221^{* * *}$ \\
\hline
\end{tabular}

${ }^{\mathrm{ab}}$ Means with dissimilar superscripts in a row are significantly different. NS=Non-significant, $* * *=$ significant at $(\mathrm{P}<0.001)$

Table 7. Expected response to selection of indigenous chicken for different traits.

\begin{tabular}{|c|c|c|c|c|c|}
\hline \multirow{2}{*}{$\begin{array}{l}\text { Selection } \\
\text { parameter }\end{array}$} & & \multirow[t]{2}{*}{ Trait } & \multicolumn{3}{|c|}{ Genotype } \\
\hline & & & ND & $\mathbf{H}$ & NN \\
\hline Expected & & ASM & -0.494 & -1.812 & -0.540 \\
\hline response & to & BW & -7.322 & -20.535 & -1.830 \\
\hline selection & & EW & -0.075 & -0.057 & 0.018 \\
\hline (R) & & EP & 0.562 & 0.932 & 0.755 \\
\hline
\end{tabular}

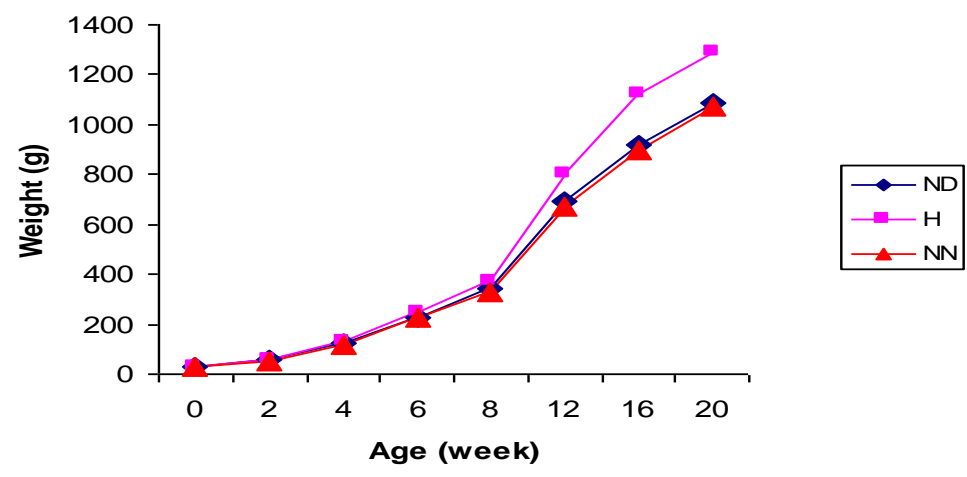

Figure 1. The average weight of indigenous chicken until the age of twenty weeks.

\subsection{Egg production}

Egg production of indigenous chicken (whole group) was significantly affected by genotype (Table 5). Higher egg production in selected group was found in H (70) genotype than ND (68) and NN (67) genotypes but difference was not significant ( $\mathrm{P}=0.07$ ) (Table 6). Higher egg production rate ( 24 weeks to 40 weeks) in selected group was observed in $\mathrm{H}(62.5 \%)$ than ND (60.7\%) and NN (59.8\%). Faruque et al. (2010a) reported that egg production rate ( 24 weeks to 40 weeks) in selected group in their three consecutive generations were 39.60, 55.93, $33.70 \%$ for ND; $33.79,50.53,39.13 \%$ for $\mathrm{H}$ and 33.36, 59.91, 37.92 \% for NN. Their findings were much lower than our present findings. Huque (1999) reported that under intensive rearing system, the annual egg production of selected Naked Neck, Hilly and Non-descript Deshi was 141, 101 and 121, respectively. Faruque et al. (2010b) observed that from starting to ten month of laying period, egg production of selected ND, $\mathrm{H}$ and $\mathrm{NN}$ was 108, 104 and 112, respectively under intensive production system.

\subsection{Egg quality}

The mean values for the qualities of eggs collected from indigenous hens kept under intensive management are presented in Table 7. Published information on egg quality of indigenous hens is very limited. Highest egg weight was found in ND (42.15 g) than $\mathrm{H}(40.08 \mathrm{~g})$ and $\mathrm{NN}(41.00 \mathrm{~g})$ genotypes but difference was not significant $(\mathrm{P}>0.05)$. Islam et al. (1981) observed that average egg weight was $35.5 \mathrm{~g}$ in indigenous chicken of Bangladesh. Khatun et al. (2005) found average egg weight of 42.94, 40.25 and $42.08 \mathrm{~g}$ respectively, for NN, $\mathrm{H}$ and ND genotypes under intensive system of rearing. This finding was more or less similar to the present finding. Significantly $(\mathrm{P}<0.001)$ highest shape index was found in $\mathrm{H}(79.20)$ than other two genotypes. Similar result was also reported by Khatun et al. (2005) who found highest shape index in H (79.0) genotype.

Breaking strength was not significantly $(\mathrm{P}>0.05)$ affected by genotype. Highest breaking strength was found in NN (0.383). Galal et al. (2000) stated that Naked Neck hen eggs were stronger in terms of shell breaking strength than normal feathered and full-feathered genotypes. Significantly $(\mathrm{P}<0.001)$ highest Haugh unit was 
found in ND (77.06) genotype. Yeasmin and Howlider (1998) observed better egg quality in indigenous fullfeathered layers compared to indigenous autosomal dwarf chickens (adw).

\subsection{Expected response to selection}

Genotype wise expected response to selection for 280 days egg production is shown in Table 7. As a result of selection, egg production is expected to improve by $0.562,0.932$ and $0.755 \%$ with minimum decrease in age at first egg of $0.494,1.812$ and 0.540 days and marginal decline in egg weight of $0.075,0.057$ and increase in egg weight of $0.018 \mathrm{~g}$, respectively for ND, H and NN genotype. Faruque et al. (2010a) reported that expected response to selection in their three consecutive generations were $0.116,0.565,0.344 \%$ eggs for ND; 0.107 , $0.337,0.411 \%$ eggs for $\mathrm{H}$ and $0.084,0.709,0.246 \%$ eggs for NN. Their findings were much lower than our present findings. Chatterjee and Misra (2000) and Singh and Singh (1997) observed the average responses to be 1.18 and 1.05 eggs per generation, respectively in different White Leghorn population. These values were much higher than the present findings.

\section{Conclusions}

Fertility, hatchability, dead in germ, mortality, egg production (whole group), egg weight, and Haugh unit were better in ND genotype. Chick weight, daily growth, FCR, live weight, egg production (selected group), shape index and expected response to selection for egg production were better in $\mathrm{H}$ genotype. On the other hand, carcass characteristics and breaking strength were better in NN genotype. These findings of the study also give an impetus for continuing the research for more generations to fulfill onward objectives of the long-term programme. It conversely means that indigenous chicken will probably respond to pure breeding selection program. However, the expected response, which has been calculated just from the selection of parents to form the generation one $\left(G_{1}\right)$, has given us this hint.

\section{Acknowledgements}

Special thanks to the authority of BLRI for taking such initiative research and all the related scientists of this work.

\section{Conflict of interest}

None to declare.

\section{References}

Ahmed ST and MA Ali, 2007. Performance of Synthetic, Desi, Synthetic x Desi and Synthetic x Star cross brown chicken at marketing. Proceedings of the $5^{\text {th }}$ International Poultry Show and Seminar. Organized by World's Poultry Science Association. Bangladesh Branch, 01-03 March 2007, pp. 18-25.

BBS ,2006. Bangladesh Bureau of Statistics. Statistical Pocket Book, Dhaka, Bangladesh.

Chatterjee RN and BS Misra, 2000. Expected response and rate of inbreeding in a closed flock of White Leghorn under long term selection. Indian Journal of Poultry Science, 35: 315-317.

Falconer DS, 1981. Introduction to Quantitative Genetics. Second Edition. Chapter 11. Selection response and its prediction. pp. 171-177.

Faruque S, MA Afroz and MS Islam, 2010a. Evaluation of response to selection in chicken. Int. J. BioRes., 1: 01-05.

Faruque S, MM Rahman and MN Islam, 2011. Evaluation of the performance of native chickens and estimation of genetic parameter for body weight. Proc. $7^{\text {th }}$ International Poultry Show and Seminar, 2011. Bangabandhu International Conference Centger, Dhaka, Bangladesh. pp. 199-205.

Faruque S, NR Sarker , MN Islam and MSK Sarker, 2007. Performance of native chickens under intensive system. Journal of Bangladesh Agricultural University, 5: 283-288.

Faruque S, NU Siddiquee, MA Afroz and MS Islam, 2010b. Phenotypic characterization of Native Chicken reared under intensive management system. Journal of Bangladesh Agricultural University, 8: 79-82.

Galal A, AH El-Attar and MM Fathi, 2000. Laying performance of naked neck and frizzled genotypes of chicken under low ambient temperature. Egyptian Poultry Science Journal, 20: 889-904.

Halima H , 2007. Phenotypic and genetic characterization of indigenous chicken populations in Northwest Ethiopia. Ph.D. Thesis, University of the Free State, Bloemfontein, South Africa.

Hossain MM , MAR Howlider and MJ Hossain, 1991. Growth performance and meat yield of Naked Neck and broiler chicken in a hot humid environment. The Bangladesh Veterinarian, 8: 4-7. 
Huque QME, 1999. Poultry Research and Development in Bangladesh. Proceedings of the $1^{\text {st }}$ Seminar and International Poultry show, April 24-26, IDB Bhaban, Sher-e- Bangla Nagar, Dhaka Bangladesh. pp. 70-80.

Islam MA, 2003. Comparison of growth rate and meat yield characteristics of cockerels between Fayoumi and Sonali under village condition. Ph. D. Thesis, Department of Poultry Science, Bangladesh Agricultural University Mymensingh.

Khatun R, MS Islam, S Faruque, SA Azmal and MS Uddin, 2005. Study on the productive and reproductive performance of 3 native gentoypes of chicken under intensive management. Journal of Bangladesh Agricultural University 3: 99-104.

Kirk S, GC Emmans, R Mcdonald and D Arnot, 1980. Factors affecting the hatchability of eggs from broiler breeders. Br. Poult. Sci., 21: 37-53.

Simons PCM, 2009. Commercial egg and poultry meat production and consumption trade worldwide. Proceedings of the 6th International Poultry Show and Seminar. The World's Poultry Science AssociationBangladesh Branch, Dhaka, Bangladesh, pp. 11.

Snedecor GW and W G Cochran, 1989. Statistical Methods, 8th edn. The Iowa State University Press, Ames, IA, USA.

SPSS (Statistical Procedures for Social Sciences), 1998. SPSS 11.5 for windows.

Statistical Pocket Book of Bangladesh, 2005. Bangladesh Bureau of statistics. pp. 415.

Yeasmin T, 2001. Effects of incorporating dwarf gene from indigenous (desi) to exotic breeds of chicken. Ph.D. Thesis, Department of Poultry Science, Bangladesh Agricultural University, Mymensingh.

Yeasmin $\mathrm{T}$ and MAR Howlider, 1998. Comparative physical Feature Egg production and Egg quality characteristics of normal and dwarf indigenous (Desi) hens of Bangladesh. Journal of Applied Animal Research, 13: 191-196. 